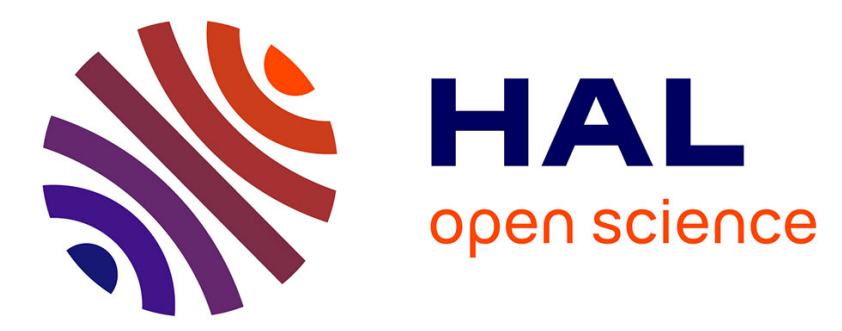

\title{
Flow, mixing and residence time distribution of maize starch within a twin-screw extruder with a longitudinally-split barrel.
}

\author{
Paul Colonna, J.P. Melcion, Bruno Vergnes, Christiane Mercier
}

\section{To cite this version:}

Paul Colonna, J.P. Melcion, Bruno Vergnes, Christiane Mercier. Flow, mixing and residence time distribution of maize starch within a twin-screw extruder with a longitudinally-split barrel.. Journal of Cereal Science, 1983, 1, pp.115-125. hal-02721419

HAL Id: hal-02721419

https://hal.inrae.fr/hal-02721419

Submitted on 1 Jun 2020

HAL is a multi-disciplinary open access archive for the deposit and dissemination of scientific research documents, whether they are published or not. The documents may come from teaching and research institutions in France or abroad, or from public or private research centers.
L'archive ouverte pluridisciplinaire HAL, est destinée au dépôt et à la diffusion de documents scientifiques de niveau recherche, publiés ou non, émanant des établissements d'enseignement et de recherche français ou étrangers, des laboratoires publics ou privés. 


\title{
Flow, Mixing and Residence Time Distribution of Maize Starch within a Twin-screw Extruder with a Longitudinally-Split Barrel*
}

\author{
P. COLONNA, J.-P. MELCION, B. VERGNES $\uparrow$ and C. MERCIER \\ Institut National de la Recherche Agronomique, Centre de Recherches \\ Agro-Alimentaires, Chemin de la Géraudière, F-44072, Nantes-Cédex, France
}

Received 28 September 1982 and in revised form 9 December 1982

\begin{abstract}
A longitudinally-split barrel was used to study the internal modifications of maize starch during extrusion-cooking in a Creusot-Loire BC-72 twin-screw extruder. After steady state conditions were obtained, the extruder barrel was dismantled and samples were taken at points along the screws in order to study changes in starch granular structure and macromolecular levels in the different phase transition zones.

Mass transport is the predominant process in the extruder before the reverse flight section where comminution is the major event. In this reverse flight zone, starch granules are progressively sheared and melted. Shear along the barrel surface causes rapid cooking, with the formation of a glassy phase. The results show that the combined effect of shear, together with heat and pressure, are mainly responsible for starch modifications. The residence time distribution is a function of extruder size.
\end{abstract}

\section{Introduction}

Extrusion-cooking is a relatively new technology and its unequalled versatility has led to many applications $\mathbf{1}^{1,2}$. Two types of substrate, starch and protein, have been studied most. Whereas starch granules are gelatinised with partial degradation of amylose and amylopectin $^{3-10}$, proteins essentially are denatured ${ }^{11}$ leading to texturisation ${ }^{12-14}$. However, extrusion-cooking has remained more of an art than a technology ${ }^{15,16}$. Surprisingly, little attention has been paid to the basic phenomena that occur during extrusion-cooking and their interrelationships with the various process variables. Only a few research papers on the underlying science of the process have been published. Aguilera et al. ${ }^{17}$, studying the microscopic alterations of soya flour ultrastructure, have observed that comminution and mixing predominate initially, until cooking temperatures are reached in the final sections of the screw; in this short zone, texturisation occurs.

In the synthetic polymer field, investigations on flow, mixing and residence-time distribution are quite rare, especially for twin-screw extruders. A few practical measure-

\footnotetext{
* This work was reported at the 5th Zentralfachshule der Deutschen Suesswarenwirtschaft-Seminar, Solingen (West Germany) 11-13 October 1982. $\dagger$ Present address: Ecole des Mines de Paris, Centre de Mise en Forme des Matériaux, Sophia Antipolis,
F-06 560 Valbonne, France
} 
ments have been reported ${ }^{18-20}$. Recently, Janssen ${ }^{21}$ has developed a mathematical model for twin-screw extruder operation, supported by experimental results. Starch processing differs in two main respects; firstly, granular starch is completely transformed into an amorphous and expanded phase, comprising partly depolymerised material; secondly, starch is always extruded with water (5-40\%, depending on extruder type), which is also a solvent for starch components.

The objective of the present study was to determine whether starch extrusion on a twin-screw extruder is analogous to synthetic polymer extrusion, as described by Janssen $^{21}$. This was achieved, using a longitudinally-split barrel by following maize starch transformations as the material progressed along the two screws of the extruder, under stable running conditions.

\section{Experimental}

\section{Materials}

Commerical maize starch ROFEC was purchased from Roquette National Chemie, Lestrem, France.

A commercial twin-screw extruder BC-45 and an experimental twin-screw BC-72 extruder (Creusot-Loire, Division Pompes et Extrudeurs, Firminy, France) were used.

The BC-72 extruder barrel comprises three main parts (Fig. 1): (a) a die block with two dies; (b) the barrel upper half, divided into three sections in order to facilitate assembly and dismantling (parts 1,2 and 3), (c) the lower half corresponding to half of a conventional barrel, after splitting longitudinally (part 4). All of these sections are held together by bolted binding collars. Therefore, the barrel can be split horizontally and rapidly dismantled to reveal the whole contents of the barrel, without disturbing the material contained within. The feeding zone is cooled by a water circulation belt. Barrel temperatures are measured with thermocouples at three points along the barrel. A combined probe for measuring pressure and temperature (Dynisco, TPT 463 E) was mounted near to the die. It should be emphasised that barrel casing temperature, and not the temperature of material within the extruder, are measured in this system.

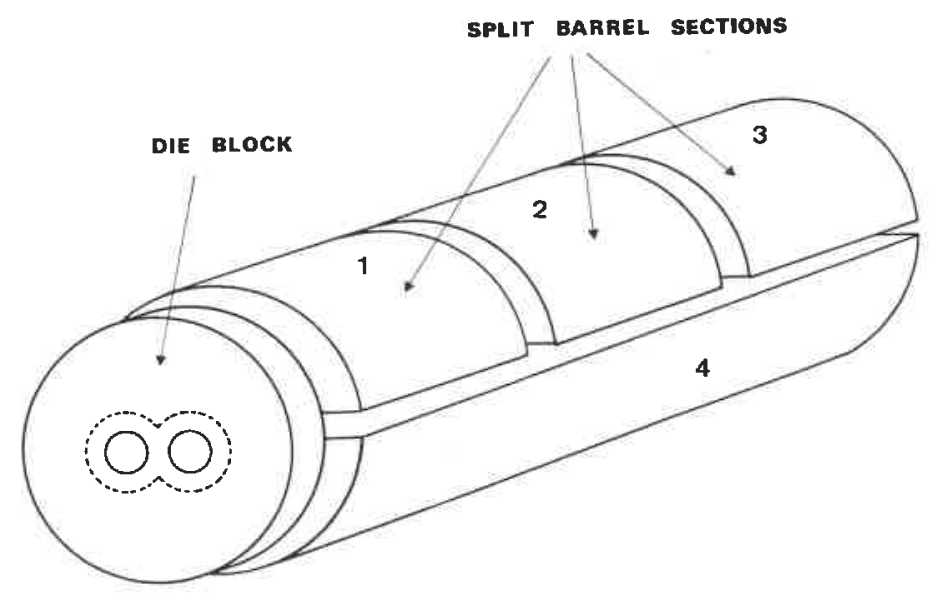

FIGURE 1. Diagram of longitudinally-split barrel from the BC-72 twin-screw extruder (see text for details). 


\section{Operating conditions}

The screw geometry is described in Fig. 2. The screws are composed of differents modules, each characterised by the length of the section and the pitch of the flight; the last module is a reverse flight, unless stated otherwise.

Extrusion parameters were in the following ranges: screw speed- $145 \mathrm{r} / \mathrm{min}$; dies$2 \times(\phi=8 \mathrm{~mm} ; L=50 \mathrm{~mm})$; length of the space screwhead-die $-1.5,2.5$ and $4.5 \mathrm{~mm}$; feed rate $-80-190 \mathrm{~kg} / \mathrm{h}$; percentage feed moisture $-17 \%$ (dry basis); maximal barrel temperature$120-160^{\circ} \mathrm{C}$; die pressure $-45-75$ bars.

\section{Residence time distribution}

The residence time distributions were measured by means of a coloured tracer (Bleu NO 517-11 Givaudan-'Cogilor'). A pellet of tracer $(0.5 \mathrm{~g})$ was added to the feeding zone. Samples were collected every $5 \mathrm{~s}$ and the absorbance $(610 \mathrm{~nm})$ of the extrudate was determined after stirring the ground starch $(600 \pm 1 \mathrm{mg})$ in $20 \mathrm{~cm}^{3}$ of $1 \mathrm{M}-\mathrm{KOH}$ for $40 \mathrm{~min}$ at $+4{ }^{\circ} \mathrm{C}$. Fig. 6 is a representation of the residence time probability distribution showing the probability that a flow element has a residence time $t$ as a function of time.

\section{Sampling from the extruder}

The extruder was operated until a steady state condition was reached $(30 \mathrm{~min})$ : at that time, pressure and temperature, which were measured at the die, were constant. Then feed, screws and heating were stopped and the barrel immediately cooled by running cold water through the cooling coils $(12 \mathrm{l} / \mathrm{min})$. At the same time, the dismantling commenced, starting at the die block and working towards the feed end i.e. sections 1,2 and 3 respectively (Fig. 1). Barrel sections were carefully raised up over the screws. The starch samples were then collected from the die and from points along the screw.

\section{Characterisation of starches}

Scanning electron microscopy examinations were carried out as described by Colonna et al. ${ }^{22}$. Photomicrographs of the starch granules in aqueous suspension were taken on an Olympus light microscope (model Vanox), equipped with polarising filters: the observance of birefringence (a black cross in polarised light) showed whether crystallinity was still present or not. Damaged starch granules were stained with aqueous Congo Red $(0.3 \%)^{23}$.

Macromolecular degradation of starch components was estimated by gel permeation chromatography of solutions in $0.1 \mathrm{M}-\mathrm{KOH}$ on Sepharose CL-2 $\mathrm{B}^{10}$ and by intrinsic viscosity measurements using an Ostwald viscometer (solutions in $0.2 \mathrm{M}-\mathrm{KOH} ; 25^{\circ} \mathrm{C} ; 88 \mathrm{~s}$ flow-time) ${ }^{10}$. The results obtained with these two methods are highly correlated and, since gel permeation chromatography is time consuming, most of the reported results are from intrinsic viscosity measurements.

\section{Results and Discussion}

Sampling, flow, mixing and residence-time distribution of maize starch extruded on a BC-72 Creusot-Loire extruder have been studied on a total of eleven samples.

Although the results have not been subjected to statistical analysis, all samples showed similar behaviour and trends and the values given in Fig. 2 may be taken as representative results. 


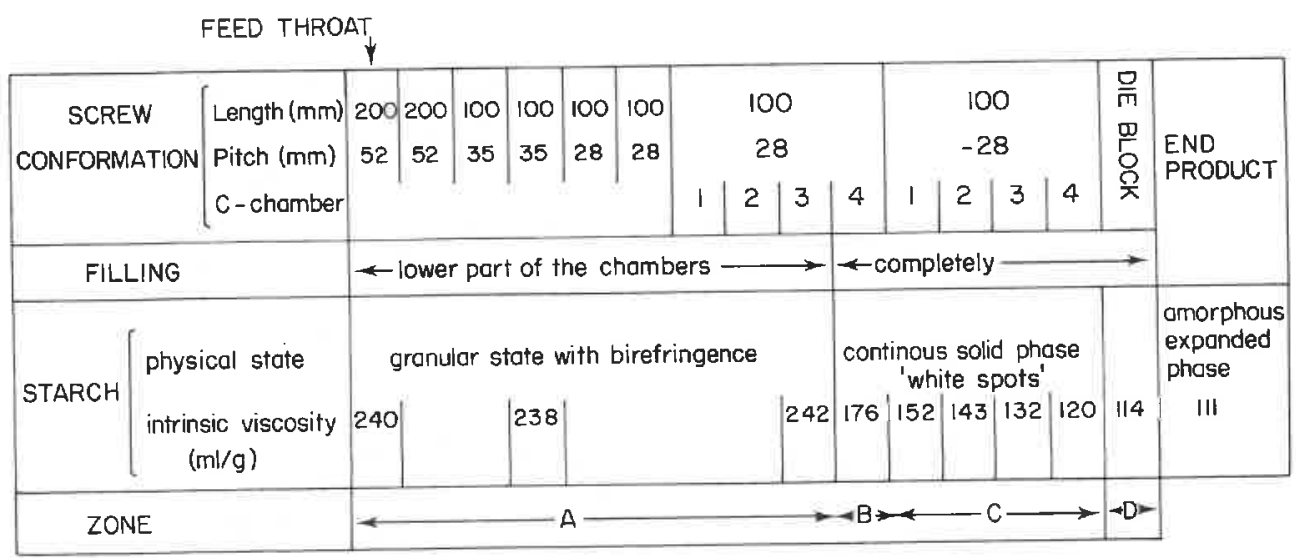

FIGURE 2. Extruder operational parameters and starch properties inside the barrel of the BC-72 extruder. (Screw speed $=145 \mathrm{r} / \mathrm{min}$; feed rate $=83 \mathrm{~kg} / \mathrm{h}$, maize starch; barrel temperature $=130^{\circ} \mathrm{C}$ ).

\section{Starch modification during extrusion-cooking}

Starting from a crystalline granular shape (Figs $3 \mathrm{a}, 3 \mathrm{~b}$ and $4 \mathrm{a}$ ) starch is transformed into an expanded material (Fig. 4b), characterized by a diametral expansion ratio of 2 and an apparent density of 0.2 . The intrinsic viscosity of native maize starch, solubilised in $0.2 \mathrm{M}-\mathrm{KOH}$ is $240 \mathrm{~cm}^{3} / \mathrm{g}$. The elution profile of Sepharose CL-2B (Fig. 5) shows a sharp peak at the void volume, representing $75.1 \%$ of the total material, followed by a long tail up to the total volume. Amylopectin, identified at the void volume by its reaction with iodine $\left(\lambda_{\max }=540 \mathrm{~nm}\right.$ ), is progressively contaminated by amylose, which is observed only after $K_{a v} 0 \cdot 38$. After extrusion-cooking (Fig. 2), the intrinsic viscosity is reduced to $111 \mathrm{~cm}^{3} / \mathrm{g}$. By gel permeation chromatography (Fig. 5), the material eluted at the void volume, which is amylopectin $\left(\lambda_{\max }=540-550 \mathrm{~nm}\right)$, is reduced to $53.2 \%$ of the total. Amylopectin-like material is observed until $\mathrm{K}_{\mathrm{av}} 0 \cdot 24$, whereas amylose is detected only after $\mathrm{K}_{\mathrm{av}} \mathbf{0} \cdot 52$. Both methods demonstrate that amylose and amylopectin are degraded by extrusion-cooking into lower molecular weight materials, confirming previous observations with manioc $\operatorname{starch}^{10}$.

\section{Sampling}

As soon as the extruder is stopped, the material inside the barrel is no longer submitted to shear, but the temperature of the mass decreases slowly. A lag time of 9 min between stopping and sampling is unavoidable and corresponds to the removal of the die block ( $5 \mathrm{~min}$ ), the first length (part 1 in Fig. 1) of the upper half of the barrel ( $2 \mathrm{~min}$ ) and the second part of the barrel $(2 \mathrm{~min}$ ). Starch, in granular form, is characterised by a low thermal conductivity like other polymers and no degradation would be expected. Indeed, no starch modification is observed in the first part of the extruder barrel. When starch is melted, only a thin layer (less than $0.5 \mathrm{~mm}$ ) of material in contact with the metal surface 


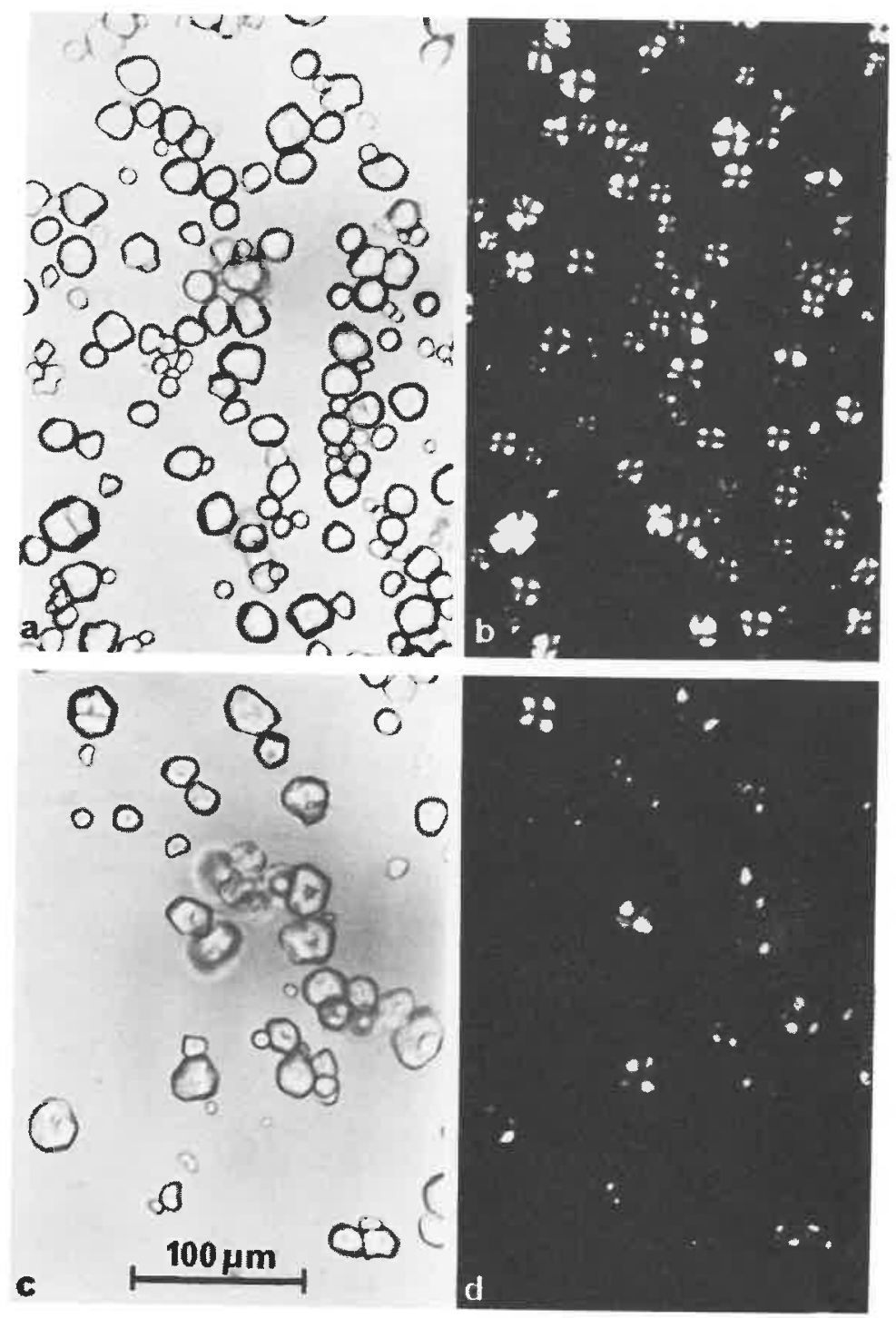

FIGURE 3. Light micrographs of maize starch samples. (a) native maize starch; (b) as (a), but photographed under polarized light; (c) starch granules from 'white spots" sampled at the beginning of zone C (see Fig. 2); (d)-as (c), but photographed under polarised light.

is cooked and this has been discarded systematically in the sampling. Moreover, macromolecular degradation (as measured by intrinsic viscosity) was unchanged for starch samples collected after $5 \mathrm{~min}\left(120 \mathrm{~cm}^{3} / \mathrm{g}\right), 7 \mathrm{~min}\left(123 \mathrm{~cm}^{3} / \mathrm{g}\right)$ and $10 \mathrm{~min}$ $\left(119 \mathrm{~cm}^{3} / \mathrm{g}\right)$ in the die block. These observations agree with previous work ${ }^{24}$ on thermal degradation of starch: molecular modifications induced by temperature (100-200 $\left.{ }^{\circ} \mathrm{C}\right)$ 

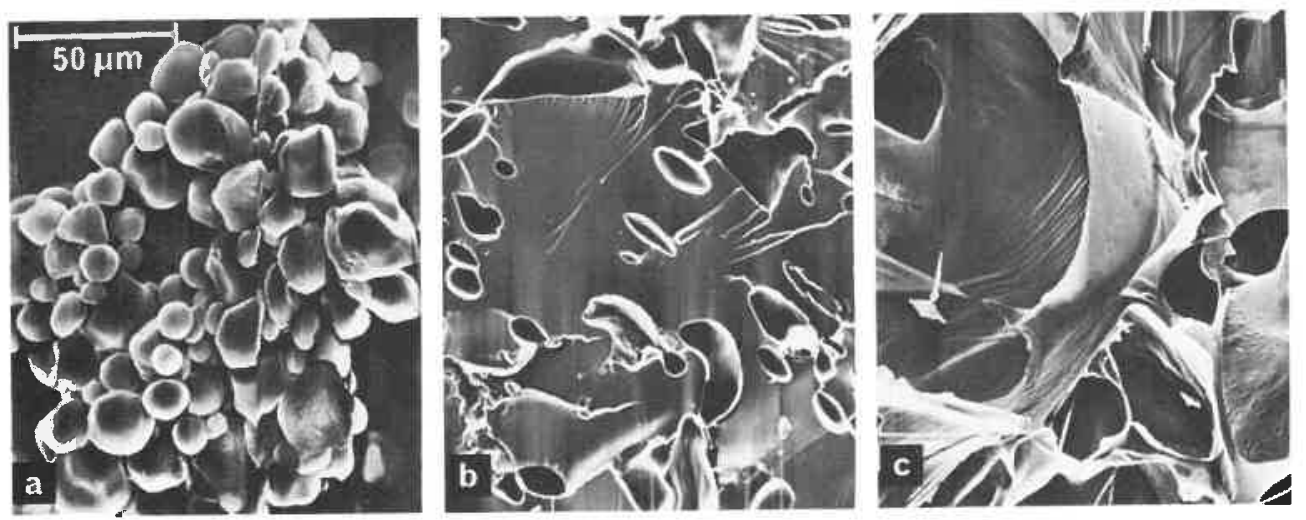

FIGURE 4. Scanning electron micrographs of maize starch samples. (a) native maize starch; (b) starch sampled in zone B (see Fig. 2); (c) extruded maize starch.

occur in the time range of 2-10 h, whereas in our experiments, sampling is carried out in less than $10 \mathrm{~min}$. Therefore, sampling should be representative for estimating the macromolecular degradation, despite the time-lag between stopping the extruder and taking samples.

In contrast, the physical transformations of starch granules may be over-estimated by our procedures. As soon as the melted starch is cooked, it becomes solid and hard. Furthermore, a small expansion (Fig. 4c) occurs when disconnecting the different sections of the barrel, which renders difficult both starch sampling and the detection of leakage of material between the screws and the barrel.

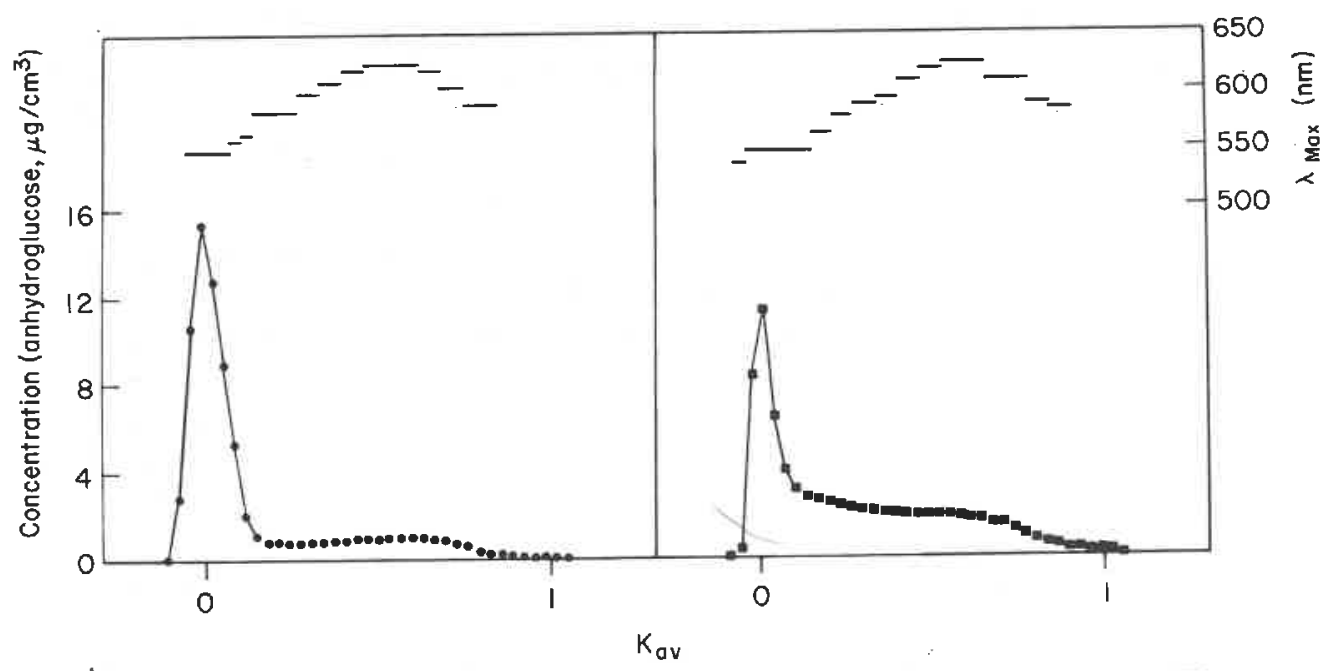

FIGURE 5. Elution profiles from Sepharose CL-2B of native (๑) and extruded (⿴囗十) maize starches, dissolved in $0 \cdot 1 \mathrm{M}-\mathrm{KOH}$. The horizontal bars represent $\lambda_{\max }$ values after addition of $I_{2} / K I$ and indicate the proportions of amylopectin $\left(\lambda_{\max } 540-550 \mathrm{~nm}\right)$ and amylose $\left(\lambda_{\max }>600 \mathrm{~nm}\right)$ in the eluted fractions. 


\section{Flow and mixing}

A twin screw extruder with closely intermeshing screws, can be represented conveniently by two series of $\mathrm{C}$-shaped chambers, one for each screw ${ }^{21}$ (see Fig. 2). These C-shaped chambers are completely independent. In the last section, where the reverse flights are located, gaps in the flights permit substantial leakages and these four last chambers are interrelated.

Four zones must be considered (Fig. 2): zone A-all the chambers located along the screw with a positive pitch (except the last one, which is adjacent to the reverse flight); zone B-the chamber located in the part of the screw with a positive flight, and just before the reverse flight; zone $\mathrm{C}$ - the four chambers located in the section of the reverse flight; zone D-the space between screw head and die block.

Zone A- conveying section': Along this zone, which is $87 \mathrm{~cm}$ long, the starch granules undergo no transformation, either in terms of granule structure, or in molecular degradation (Fig. 2). The function of this zone is to receive the raw ingredient and to transport the material uniformly forward; the material remains in its native state whilst being forced along the barrel. No compression at all is observed, although solid bed is repeatedly disordered by the intermeshing flights. It is clear that in these chambers, where a considerable amount of air is present, the material is present as individual starch granules. Only the lower portion of the chambers is filled, the level being proportional to the feed rate. There is little exchange of material between chambers, only the one resulting from surface drag effects.

The flow of material can be regarded as being a relatively straight forward movement at a speed slightly lower than the flight displacement velocity. An increase of temperature in the feeding zone by stopping the water circulation belt can cause 'clamping' of the extruder. One explanation could be that the polymer melts and adheres to the screws, increasing greatly the power necessary to convey the material along the barrel. Another function of this zone is to smooth out any instability in the feed rate.

Zone B-first 'transition section': In these two chambers (one for each screw, Fig. 2), the starch is progressively compressed and transformed into a dense, solid, compact and corneous material (Fig. 4c), whereas granular and crystalline structures disappear. However, this transformation is not complete. 'White spots', composed of agglomerated crystalline starch granules, are still observed; the absence of staining by Congo Red demonstrates that granules are still intact. For the glassy phase, the decrease in the intrinsic viscosity, $[\eta]$, of starch means that a macromolecular degradation is occurring at this stage. This transformation is higher near the barrel surface $\left([\eta]=63 \mathrm{~cm}^{3} / \mathrm{g}\right)$ than in the screw core $\left([\eta]=199 \mathrm{~cm}^{3} / \mathrm{g}\right)$. The filling is a positive function of the feed rate, never exceeding these two last $\mathrm{C}$-shaped chambers.

This zone provides mechanical work, resulting in the melting of starch and must be called the 'transition section'. The transformation seems to be independent of operating temperature under our conditions, indicating that pressure and shear are the two main factors in this zone. 
Zone C-second 'transition section': The screw chambers are completely filled. The 'white spots' disappear progressively from the first to the fourth turn. In each chamber, the amount of 'white spots' material is less near the barrel surface than near the screw core. The starch granules progressively loose their birefringence (Figs 3c and 3d) and, finally, are completely stained by Congo Red, demonstrating that the starch granules are gelatinised whilst maintaining their overall shapes. The intrinsic viscosity of starch decreases during its progress along the screws and is also higher near the screw core $\left(150 \mathrm{~cm}^{3} / \mathrm{g}\right)$ than near the barrel surface $\left(111 \mathrm{~cm}^{3} / \mathrm{g}\right)$ for the fourth $\mathrm{C}$-chamber of the screw (Fig. 2).

In this zone, the material is pushed back, but leaks through the gaps between the flights. The starch is homogenised by shearing of the melted granules. Under our conditions, the volume fraction of water ${ }^{25}$ is around $0 \cdot 10$, giving a melting point $\left(T_{m}\right)$ of the most perfect crystallites, around $160^{\circ} \mathrm{C}$, according to Donovan ${ }^{26}$. From previous work of Mercier et $a l^{9}$ it is interesting to note that maize starch has to be extruded at least at $170^{\circ} \mathrm{C}$ to cause complete disappearance of the ' $\mathrm{A}$ ' type $\mathrm{X}$-ray diffraction pattern. As in the present experiments, the measured temperature is that of the barrel and not of the starch, explaining why the observed temperatures do not correspond to the $T_{m}$. Thermal modifications seem to be predominant in this zone, after which starch must be considered as a completely plasticised mass.

Zone $D$-'discharge section': This volume is completely filled and the material is homogeneous. However, some dead zones are observed at the external part of the die block, showing higher intrinsic viscosities $\left([\eta]=122 \mathrm{~cm}^{3} / \mathrm{g}\right)$ and therefore lower macromolecular degradation. Passage through the dies does not cause modification of the macromolecular structure of starch, indicating that the dies no not produce enough shear to degrade starch molecules.

The above description of the extrusion process for starch is completely different from that proposed by Janssen ${ }^{21}$ for twin-screw extruders, processing synthetic polymers. The most important feature is the reverse flight, which plays an important function of mixing and shearing. Even if shear is unmeasurable with the present kind of screw geometry, this physical parameter plays a major role. The conventional assumption that twin-screw extruders are low shear systems should be reconsidered ${ }^{2}$. In comparison to single screw extruders, the main difference is the existence of a short zone of transformation, compared with single screw extruders in which starch transformation ${ }^{27,28}$ and protein modification ${ }^{17}$ occur progressively along the screw.

\section{Residence time distribution}

The residence time distributions are illustrated in Fig. 6. The mean residence time is between 30 and $45 \mathrm{~s}$, depending on extrusion conditions, with an early breakthrough at $5 \mathrm{~s}$ and a long tail up to $170 \mathrm{~s}$. The asymmetrical coefficient $\gamma_{1}$, calculated as the ratio of moment of order 3 divided by the moment of order 2 raised to the $3 / 2$ th power $^{29}$, is high $\left(\gamma_{1}=2 \cdot 3\right)$. Assuming that starch progress in zone $A$ at the speed of the flight velocity, without back-leakage, the time necessary to reach zone $B$ and $C$ is about $10 \mathrm{~s}$. Therefore, the mixing in zones $\mathrm{B}$ and $\mathrm{C}$, and the flow in zone D needs from 15 to $25 \mathrm{~s}$. Using a 


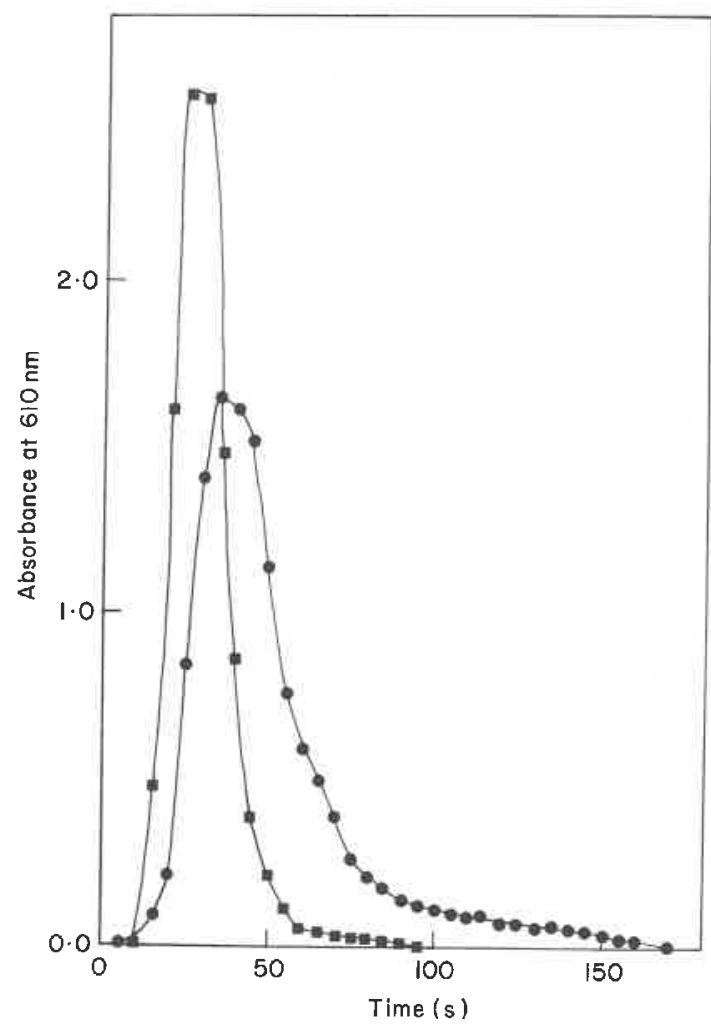

FIGURE 6. Residence time distributions of maize starch measured on the BC-72(0) and $\mathrm{BC}-45$ (물 ) twin-screw extruders. Operating conditions were, for the BC-72 and BC-45 extruders, respectively; screw speeds, 150 and $160 \mathrm{r} / \mathrm{min}$; starch feed rates, $96 \mathrm{~kg} / \mathrm{h}$ and $63 \mathrm{~kg} / \mathrm{h}$; barrel temperatures, $150^{\circ} \mathrm{C}$ and $160^{\circ} \mathrm{C}$.

Creusot-Loire BC-45 twin-screw extruder with the same geometry, but with a shorter screw, the residence time distribution (Fig. 7) was measured and gave a mean residence time between 20 and $40 \mathrm{~s}$, a tail up to $90 \mathrm{~s}$, an asymmetrical coefficient, $\gamma_{1}$, of 1.7 and a lag time of $10-20 \mathrm{~s}$ to pass through the reverse flight.

These results, which agree with those of Olkku et al. ${ }^{30}$ confirm the rule that the screw conformation affects mass flow just in front of the screw element with a reverse pitch. The $\mathrm{C}$-shaped chambers are filled, affecting product processing by a significant broadening of the residence time distribution. Nevertheless, the time necessary to pass through the reverse flight appears shorter on the BC-45 extrusion (10-20 s) than on the BC-72 model $(15-25 \mathrm{~s})$. These discrepancies emphasise the difficulties encountered by engineers in scaling-up of extruders. In contrast, Mosso et al. ${ }^{31}$ obtained longer residence time means $(50-60 \mathrm{~s})$, which could be ascribed to different screws and barrel geometries, as the reverse flight was followed by a normal screw section in their work. Residence time distributions, measured on single extruders ${ }^{25,31}$, are similar to those in our studies. 


\section{Conclusions}

The facility for dismantling the extruder barrel in longitudinal sections has allowed an examination of the properties of starch-water systems at different stages of the extrusion process. These observations with the twin-screw extruder have shown that mass transport, without physical or chemical modification of starch, is the predominant process in the extruder before the reverse flight section. Thereafter, comminution and mixing are the major processes and, in this section, physical changes in granule structure and partial degradation of the starch molecules occur during a very short period of 10-20 s. These changes are caused by simultaneous effects of temperature, pressure and shear. Shear is impossible to measure directly, due to the complex geometry of the reverse flight screw system. The absence of accurate measurements of temperature and pressure profiles in twin-screw extruders represent serious gaps in present knowledge. Further work with this system will aim to improve instrumentation of the extruder, accompanied by laboratory-scale simulation of starch shearing.

The authors thank the Creusot-Loire staff, especially M Spriet for allowing us to operate the experimental extruder, and Mlle B. Bouchet (I.N.R.A., Nantes) for performing the scanning electron microscopy.

The investigation was supported by grant no. 81.C.0170, awarded by the French Ministry of Research and Industry.

\section{References}

1. Linko, P., Colonna, P. and Mercier, C. in 'Advances in Cereal Science and Technology' (Y. Pomeranz, ed.), Am. Assoc. Cereal Chem. St Paul, Minnesota (1981) vol. 4, pp 145-235.

2. Harper, J. M. 'Extrusion of Foods' Vol. 1 and 2, CRC Press, Boca Raton, Florida (1981).

3. Lawton, B. T., Henderson, G. A. and Derlatka, E. J. Can. J. Chem. 50 (1972) 168-172.

4. Lorenz, K. and Johnson, J. A. Cereal Chem. 49 (1972) 616-628.

5. Charbonniere, R., Duprat, F. and Guilbot, A. Cereal Sci. Today 18 (1973) 286.

6. Mercier, C. and Feillet, P. Cereal Chem. 52 (1975) 283-297.

7. Mercier, C. Stärke 29 (1977) 48-52.

8. Linko, Y. Y., Lindgroos, A. and Linko, P. Enz. Microbiol. Technol. 1 (1979) 273-278.

9. Mercier, C., Charbonniere, R., Gallant, D. and Guilbot, A. in 'Polysaccharides in Food' (J. M. V. Blanshard and J. R. Mitchell, eds.), Butterworths, London (1979) pp 152-170.

10. Colonna, P. and Mercier, C. Carbohydr. Polym. 3 (1983) 87-108.

11. Jeunink, J. and Cheftel, J. C. J. Food Sci. 44 (1979) 1322-1325.

12. Horan, F. E. in 'New Protein Foods" vol. 1. (M. Altschul, ed.), Academic Press, New York (1974) pp 366-404.

13. Harper, J. M. Crit. Rev. Food Sci. Nutr. 11 (1979) 155-215.

14. Kinsella, J. E. Crit. Rev. Food Sci. Nutr. 10 (1978) 147-207.

15. Smith, O. B. in 'New Protein Foods' vol. 2(M. Altschul, ed.), Academic Press, New York (1976) pp 86-121.

16. Smith, O. B. Cereal Foods World 21 (1976) 4-8.

17. Aguilera, J. M., Kosikowski, F. V. and Hood, L. F. J. Food Sci. 41 (1976) 1209-1213.

18. Jewmenov, S. D. and Kim, W. S. Plaste und Kautschuk 20 (1973) 356-364.

19. Tood, D. B. Pol. Eng. Sci. 15 (1975) 437-441.

20. Janssen, L. P. B. M. and Smith, J. M. in 'Proceedings Congress on Polymer Rheology and Plastic Processing' PRI/BSR, Loughbourough (1975) pp 160-169.

21. Janssen, L. P. B. M. 'Twin Screw Extrusion' (S. W. Churchill, ed.), Elsevier, Amsterdam (1978).

22. Colonna, P., Gallant, D. and Mercier, C. J. Food Sci. 45 (1980) 1629-1636.

23. Jones, C. R. Cereal Chem. 17 (1940) 133-169. 
24. Greenwood, C. T. in 'Advances in Carbohydrates Chemistry' vol. 22, (M. L. Wolfrom, ed.), Academic Press, New York (1967), pp 483-515.

25. Donovan, J. W. Biopolymers, 18 (1979) 263-275.

26. Donovan, J. W. Fed. Proc. Fed. Ann. Soc. Exp. Biol. 37 (1978) 1712.

27. Zuilichem, D. L., de Swart, J. G. and Buisman, G. Lebensm. Wiss. u. Technol. 6 (1973) 184-188.

28. Paton, D., Roberston, G. D., Timbers, G. E. and Spratt, W. A. J. Food Sci. 45 (1980) 224-227.

29. Dagnelie, P. in 'Theories et methodes statistiques: Applications Agronomiques' vol. 1. (J. Duculot, ed.), Presses Agronomiques de Gembloux, Gembloux, Belgium (1969) pp 46-48.

30. Olkku, J., Antila, J., Heikkinen, J. and Linko, P. in 'Food Process Engineering' vol. 1. (P. Linko, Y. Malkki, J. Olkku and J. Larinkari, eds.), Applied Science Publishers, London (1980) pp 791-794.

31. Mosso, K., Jeunink, J. and Cheftel, J.-C. Ind. Aliment. Agric. 99 (1982) 5-18.

32. Zuilichem, D. J. and Stop, W. in 'Intl. Snack Seminar'. October 18-21, Central College of German Confection Institute, Solingen, Germany (1976). 
